\title{
aniki
}

Revista Portuguesa da Imagem em Movimento

Portuguese Journal of the Moving Image

\section{Um saber montado: Georges Didi-Huberman a montar imagem e tempo ${ }^{1}$ Daniela Queiroz Campos ${ }^{2}$}

\section{As imagens em relação}

As imagens não falam de forma isolada, precisamos colocá-las em relação. Essa é uma das grandes questões repetidamente formuladas pelo filósofo e historiador da arte francês Georges Didi-Huberman. Sua vasta produção - construída durante uma trajetória de mais de 40 anos de pesquisa perpassou diferentes temporalidades $\mathrm{e}$ espacialidades num mundo-imagem. Suas pesquisas abordaram díspares épocas, locais e formas imagéticas; as escolhas narrativasliterárias que deram forma a estas investigações também se apresentam bastantes variáveis nesse percurso intelectual. Contudo, algumas questões são centrais para a compreensão da obra didihubermaniana; grosso modo, o filósofo manteve-se a pensar, escrever e questionar as imagens sobre sólidas bases teóricas.

De Invention de l'hystérie: Charcot et l'iconographie photographique de la Salpêtrière - tese doutoral orientada por Humbert Damish e defendida na École des Hautes Études en Sciences Sociales (EHESS) de Paris no ano de 1981, com atual publicação em língua portuguesa pela editora Contraponto (DidiHuberman 2015a) - a Peuples en Larmes, peuples en armes. L'œil de l'histoire, 6 (Didi-Huberman 2016) - seu mais recente livro editado -, somam-se mais de 50 obras. Para além de livros e artigos, destacam-se seus seminários - que ocorrem, via de regra, nas primeiras e terceiras segundas-feiras do mês no Auditório de Institut National de Histoire de l'Art (INHA) - e suas exposições. O mais recente, Soulèvement, deverá percorrer cinco países, e sua primeira versão foi realizada na afamada Galeria de Arte parisiense Jeu de Paume entre 18 de outubro de 2016 e 15 de janeiro de 2017.

O directeur de recherche da École des Hautes Études en Sciences Sociales (EHESS) de Paris ressalta como um dos grandes nomes da atualidade que perpassam pelas questões da imagem. Em sua consolidada obra destacam-se, de maneira geral, três importantes questões da imagem. A primeira: saber ver mais, olhar e olhar mais,

\footnotetext{
${ }^{1} \mathrm{O}$ presente artigo apresenta-se como fruto de pesquisa de pós-doutoramento realizado na École des Hautes Études en Sciences Sociales (EHESS) de Paris sob a supervisão do Professor Doutor Georges Didi-Huberman e com bolsa consentida pelo CNPq.

${ }^{2}$ Centre d'Histoire et de Théorie des Arts, École des Hautes Études en Sciences Sociales, École des Hautes Études en Sciences Sociales, 75006 Paris, França.
} 
ver e ver de novo; atravessar o esgotamento do olho cansado da mesma imagem. A segunda: compreender a imagem não como uma solução ou uma reposta, mas com uma verdadeira problemática, um verídico problema. A terceira - a questão mote deste artigo: colocar as imagens em relação.

Colocar as imagens uma ao lado das outras. Um aparentemente simples, mas verdadeiramente complexo exercício, sempre ensaiado e insistido por Georges Didi-Huberman. Como leitora, aluna e orientanda, não poderia lembrar-me o quanto escutei e li tais dizeres vindos da boca e das mãos de alguém que parece não cessar de encaixar e desencaixar imagens. No hoje "clássico" Diante do tempo (Didi-Huberman 2008), o exemplo do relógio é singular. Desmontar as peças de um relógio, para então remontá-lo.

Os historiadores ensaiam montar imagens para, se não buscar um passado histórico, melhor compreendê-lo, para melhor problematizar esses cristais de tempo - para escrever segundo a compreensão de história de Walter Benjamin (2008). Num seminário no INHA - ministrado exatamente no dia 2 de março de 2016 -, Didi-Huberman dera outro exemplo de montagens de imagens e sua problemática para com a temporalidade. O cartomante, tal qual o detetive e o historiador, também monta imagens umas ao lado das outras. Essa montagem imagética não busca, pois, os cristais de um tempo que já se foi, mas uma premonição do tempo que advier.

O exercício da montagem de imagens não está restrito nem a um fazer, nem mesmo a um tempo; é, por si só, múltiplo. Foram muitos os que montaram, como ainda são muitos os que continuam a montar imagens. Obviamente, nas páginas que se seguem dar-se-á exemplos de teóricos e intelectuais que fizeram tais montagens: Walter Benjamin, Aby Warburg e Sergueï Eisenstein. Contudo, vale sublinhar que o dispor de imagens em relação nem é um saber exclusivamente académico/universitário, nem pode ser isolado numa época específica. Para tal, temos não somente o excelente exemplo do cartomante de Georges Didi-Huberman, como também o colocado pelo historiador da cultura visual W.J.T. Mitchell, em sua fala Method, Madness and Montage. On Global Image Overload,” no colóquio Quand les images viennent au monde? $?^{3}$. Na ocasião, Mitchell apontou e problematizou os quadros associativos imagéticos que figuram nos clássicos filmes policiais norte-americanos.

\footnotetext{
${ }^{3}$ O Colóquio Quand les images viennent au monde? foi organizado por Emmanuel Alloa e Chiara Cappelletto e realizou-se em Paris, no auditório do Jeu de Paume entre 4 e 5 de junho de 2015.
} 


\section{A operação de (des)montagem e a malícia visual do tempo na história}

Comecemos não por montagens, mas por uma operação de desmontagem. Pensar a montagem didi-hubermaniana pressupõe pensar a desmontagem, uma vez que, para o intelectual, se precisamos montar imagens é porque as imagens desmontam. "A imagem desmonta a história" (Didi-Huberman 2008, 173), a imagem seria a malícia visual do tempo na história; ela seria a malícia na história. Pois bem, o referido exemplo do relógio: a imagem desmonta a história como uma pessoa desmonta um relógio. Para desmontar um relógio precisa de se desencaixar meticulosamente as peças de sua máquina. Em tal dinamismo, o relógio, obviamente, para de "contar as horas." Contudo, fazer com que o relógio pare de funcionar é imprescindível para a boa compreensão do funcionamento de sua aparelhagem. Desmonta-se um relógio para interromper sua máquina de "contar o tempo," mas também para entender seu trabalho, o que é indispensável para repará-lo. "Tal é o duplo regime do verbo desmontar: de um lado a queda turbulenta, e de outro, o discernimento, a desconstrução estrutural” (Didi-Huberman 2008, 173).

Marc Bloch escreveu em seu rememorável $A$ apologia da história (Bloch 2002) que o historiador deveria montar o fio da história. Assim poderemos fazê-lo, se acreditamos que a história tenha um curso homogéneo e linear. Para Didi-Huberman, fazer a montagem do fio da história é estar de acordo com seu curso contínuo - sem acidentes, bifurcações ou descontinuidades temporais. De tal feita, Didi-Huberman questiona se o historiador deveria compor montagens ou desmontagens para compreender a operação histórica. Portanto, a dissociação prévia das atividades que constituem uma narrativa histórica - de "fatos", "dados" ou "fonte" - torna-se imperativa. A desmontagem é primordial para o procedimento da montagem histórica; logo, a operação historiográfica obedece a uma dinâmica de remontagem.

O historiador remonta os fragmentos, pois eles têm em si uma dupla capacidade: desmontar a história e montar um conjunto de tempos heterogéneos. Sendo assim, o historiador conjuga o agora ao tempo passado, sintomas a sobrevivências e crises a latências. A montagem não só caracteriza o objeto do conhecimento histórico, como também aparece como operação desse mesmo conhecimento (Didi-Huberman 2008, 175).

"Mas o que é um tempo remontado? É um tempo rachado, colocado em pedaços, feito visível nos seus intervalos e descontinuidades de seus fragmentos, uma simples sucessão quando uma imagem substitui sua precedente e a faz desaparecer" (Didi-Huberman 2010a, 143). Nessa analogia, montar é tomar o tempo e fazê-lo rachar, é abri-lo. Colocá-lo em pedaços, para então restituir cada uma dessas migalhas. Para tal, podemos pensar no 
corpo apresentado pelos artistas renascentistas, como o fez DidiHuberman em Ouvrir Vénus (1999). Para apresentar um belo corpo anatómico e mimético das telas e das esculturas, os artistas do Renascimento precisaram romper a carne humana e desmontar corpos. Alberti em Da Pintura (1452) já escreveu - antes mesmo de Leonardo Da Vinci - sobre a abertura e a dissecação de cadáveres. Alberti redigiu que, para apresentar um corpo nu, o artista deveria vestir os ossos com músculos, os músculos com carne e a carne com pele. Os artistas precisavam desmontar corpos, colocá-los em migalhas. Foi o conhecimento anatómico que possibilitou a exímia representação corpórea nas artes do Renascimento italiano. O historiador deveria agir da mesma maneira que aqueles artistas: desmontar o tempo e colocá-lo em pedaços na sua mesa de trabalho, para então recompô-lo. Somente conhecendo o tempo em pedaços se pode compreendê-lo.

Para Georges Didi-Huberman, as montagens devem ser construídas com base nas semelhanças das imagens, semelhanças estas que pertencem à ordem do inverificável. Didi-Huberman utiliza-se de Walter Benjamin e de sua doutrina da semelhança como aparato: as semelhanças da ordem das configurações sensíveis. "Montar não é assimilar. Somente um pensamento trivial nos sugere que, se está do lado, deve ser igual. Somente uma propaganda publicitária pode nos fazer acreditar que um carro e uma garota são da mesma natureza pela simples razão de que os vemos juntos" (Didi-Huberman 2004, 224).

No texto Les condition des images, Didi-Huberman (2011) aponta a montagem como atividade constituída com base na aleatoriedade, na vitalidade e no ritmo - o trabalho combinado destes três aspetos poderia ser denominado de um "conhecimento por montagem." As mais de mil imagens montadas no Atlas Mnemosyne foram dispostas por Aby Warburg em 79 pranchas; a eleição e a disposição destas imagens foram efetuadas por escolhas que perpassaram alguns elementos de arbitrariedade e acaso. De tal feita, esse colocar as imagens em relação é repetidamente relacionado com o aleatório, o vital e o ritmo - o amálgama destes três aspetos que constituem tal conhecimento. "Quando colocamos as cartas, estamos, em efeito, numa operação de acasos. Mas seu coração não bate por acaso, nem suas pálpebras, nem as asas de uma borboleta. E se vamos bater um tambor, é melhor estarmos no ritmo" (Didi-Huberman 2011, 92).

Na elaboração de seu Atlas Mnemosyne, Aby Warburg teria alcançado este conhecimento por montagem, ao organizar em 79 pranchas, imagens e textos dos mais diferentes tipos que foram montados e encaixados mediante escolhas. Fotografias de Roma, afrescos de Rafael, xilogravuras antissemitas, imagens esportivas. $\mathrm{O}$ embaralhar de cartas, um jogo de livres associações destes dados aleatórios. Entre todas estas articulações montadas, algo produz 
efeito sobre nosso conhecimento inteligível. As aproximações de diferentes tipos de imagens, de algum modo, produzem modificações sobre elas. Uma espécie de abertura em nossa memória, uma abertura em nosso olhar.

Estes novos conjuntos rítmicos propostos nos mostram um mundo de imagens. Montagens sensíveis que nos colocam diante de novas inteligibilidades, novas obras, novos ritmos, novas visibilidades, novas imagens, novas montagens. As imagens agrupadas naqueles painéis móveis - montadas e desmontadas - estão permeadas de anacronismos, encontros de temporalidades, sobrevivências. Didi-Huberman entende tal mapa como uma forma visual de conhecimento (2002).

"Da mesma forma que na dança, o trabalho de montagem vai e vem" (Didi-Huberman 2010a, 146). O trabalho de montagem organiza-se, cria figuras, constitui ato de conhecimento e ato de decisão. Todavia, a posição de cada um desses fragmentos pode se modificar, até decidirmos que a dança acabou, ou que a atividade de montagem teve fim. O trabalho de montagem é sempre suscetível de um recomeço; por conseguinte, é visualmente aberto. Os mesmos materiais montados de formas diferentes possibilitam novos recursos para o pensamento (Didi-Huberman 2010a, 146).

\section{A imagem a (des)montar o tempo em Walter Benjamin}

Os escritos elaborados por Walter Benjamin destacam-se por sua pertinência no entendimento da obra de Georges Didi-Huberman. Benjamin consiste num excelente ponto de partida, uma vez que atualmente seus textos são de larga circulação em diversas áreas de conhecimento, bem como de larga circulação e aceitabilidade em diversas áreas de conhecimento.

Entre a inquestionável contribuição da obra de Walter Benjamin para a compreensão do século XX e da contemporaneidade, aqui destacamos a montagem e a imagem. Georges Didi-Huberman assinala que a imagem em Walter Benjamin tem, resumidamente, a função de desmontar a história, “[...] já que ela sobrevive, e sobrevivendo ela monta e desmonta o tempo. A imagem será então a malícia visual do tempo na história" (Didi-Huberman 2005, 1).

"Tomar a história a contrapelo" é umas das expressões mais renomadas de Benjamin. Citada e recitada por incontáveis autores, a expressão foi escrita no ano de 1940, em seu texto - atualmente célebre Teses sobre o conceito de história. Uma questão mote de tal expressão versa a crítica elaborada por Benjamin acerca dos modelos temporais (Didi-Huberman 2008, 138). "Tomar a história a contrapelo" seria então compreender o curso temporal como movimento dialético. "Refundar a história 'a contrapelo', é apostar num conhecimento por montagem que faz do não saber - a imagem aparecida, 
ordinária, turbulenta, entrecortada, sintomática - o objetivo e o momento heurístico de sua mesma continuação" (Didi-Huberman 2008, 174). A obra de Benjamin questiona fortemente a questão temporal herdada do historicismo do século XIX, que propunha um evolucionismo na sua filosofia do progresso. A elaboração sobre as imagens de Walter Benjamin estabeleceu novos modelos temporais. O desafio consistiu em atualizar os modelos temporais, questionar os paradigmas, de certa feita, idealistas do historicismo oitocentista e almejar modelos menos triviais.

O desafio empreendido por Benjamin - de atualizar os modelos de temporalidades da história - compreendia escrever uma História que contrariasse violentamente o sentido do pelo. A chamada por ele de imagem dialética, então desmontaria a História - a desorientaria. Tal, então novo, modelo de temporalidade tinha a imagem como centro neurológico da "vida histórica" (Didi-Huberman 2008, 143). A imagem não era percebida na história como um ponto sobre a linha, que expressava e direcionava o curso de um passado histórico. Nas compreensões de Walter Benjamin, a imagem não constitui simples acontecimento no devir histórico; todavia,também não seria um bloqueio de eternidade insensível às condições desse devir. Nesse sentido, as questões benjaminianas aproximam-se das colocadas por Aby Warburg. Ambos compreenderam a imagem a partir de sua dupla problematização temporal.Para tal, Walter Benjamin utilizou-se do termo imagens dialéticas, quando Aby Warburg falou de polaridades.

Para Benjamin, seria a partir das imagens dialéticas que floresceria a construção de um novo olhar histórico - um olhar que possibilitaria uma "história a contrapelo"- que assinalasse a falsa continuidade temporal. "A história é objeto de uma construção cujo lugar não é o tempo homogéneo e vazio, mas um tempo saturado de "Agoras"' (Benjamin 2002, 229). Esta relação entre Agora e Outrora se dá num lampejo, apresenta-se como a relação do instante com o fóssil, do lampejo com a latência. São justamente tais relações que, para Benjamin, marcam a atualidade desta imagem. Uma imagem que tem o poder de desmontar e desconstruir a História.

As imagens dialéticas seriam, assim, imagens autênticas. Elas seriam imagens em crise, imagens que criticariam elas próprias e principalmente nossa maneira de vê-las. "Na medida em que nos olha, ela nos obriga a olhá-la verdadeiramente. E nos obriga a escrever esse olhar, não para 'transcrevê-lo', mas para construí-lo" (DidiHuberman 2010b, 172). Seligmann-Silva aponta que "o conceito benjaminiano de imagem dialética é o resultado dessa conceção da historiografia como destruição da 'falsa aparência da totalidade', ou seja, de nossas narrativas e imagens encobridoras" (Seligmann-Silva $2016,68)$. O mesmo conceito de imagem dialética critica uma conceção linear não apenas da História, mas do próprio conhecimento. É 
interessante perceber que Benjamin trouxe à tona a crítica de todo um modelo de razão e de racionalidade (Seligmann-Silva 1993).

Os conceitos acerca da imagem dialética e da montagem atravessam de forma não sistematizada a obra benjaminiana. Tais questões acerca da imagem podem ser encontradas nas páginas d'A origem do drama barroco alemão, em Sobre o Conceito de história, em Surrealismo: o último instantâneo da inteligência europeia, ou em Obra de arte na era de sua reprodutibilidade técnica (Benjamin 2002). Todavia, sua obra Passagens (Benjamin 2010 merece, aqui, singular destaque, pois é escrita no intento de redigir páginas que abordem nas suas próprias organizações o conhecimento montagem.

O livro/projeto Passagens traz as notas de uma Paris do século XIX; neste intento, a montagem é reivindicada como método e forma de conhecimento (Didi-Huberman 2008, 174). Nas palavras do próprio Benjamin, aquele era o "trabalho de desenvolver ao máximo a arte de citar sem usar aspas. Sua teoria está intimamente ligada à montagem" (Benjamin 2010, 500). Aquele conjunto de notas organizadas através de montagens apresenta díspares colocações e preocupações de Walter Benjamin acerca da imagem. Uma das principais inquietações apresentadas consiste na discussão acerca da imagem e de sua problematização diante do tempo. "Não é preciso dizer que o passado esclarece o presente ou que o presente esclarece o passado. Uma imagem, pelo contrário, é aquilo em que o Outrora encontra o Agora num relâmpago para formar uma constelação" (Benjamin 2002, 504). Neste excerto, as imbricações temporais foram sublinhadas por Benjamin. O encontro de passado e presente, ou melhor, do Outrora com o Agora, marcam uma visão temporal não cronológica. A imagem, mais uma vez no livro das Passagens, marca-se por este encontro de tempos, de tempos não homogéneos nem lineares.

"Articular historicamente o passado não significa conhecê-lo 'como ele de fato foi'. Significa apropriar-se de uma reminiscência, tal como ela relampeja no momento de um perigo" (Benjamin 2010, 224). Esta imagem do passado para Benjamin marca-se como relampejo - pois o passado não se constitui como elemento imóvel. O passado é uma imagem que se aproxima para afastar-se, que se aproxima para mostrar-se distante. O passado emerge a partir de nossas experiências do presente; é a partir e através delas que problematizamos arquivos de textos, imagens e testemunhos de passado.

Torna-se interessante problematizar a montagem tal como abordada por Walter Benjamin através de sua conexão com os princípios da montagem surrealista, principalmente elaborados pelos animadores da revista Documents. O surrealismo é principalmente analisado por Benjamin pelo desencaminhamento imaginativo no seu texto O surrealismo: o instante da inteligência europeia, publicado no ano de 1929. Não poderíamos deixar de citar aqui que a monta- 
gem cinematográfica foi problematizada e teorizada nesta mesma época, principalmente por Sergueï Eisenstein. Nas páginas seguintes serão também abordadas perspetivas da montagem nas obras deste cineasta soviético. De momento, apenas pontuamos a forte ligação que Eisenstein, como Benjamin, teve com os textos e artistas surrealistas durante sua estada em Paris.

Grosso modo, e resumidamente, o princípio da montagem em Benjamin consiste em destacar singularidades pensadas através de suas relações, nos seus movimentos e nos seus intervalos (DidiHuberman 2010, 14). Consiste em perceber um cristal do evento total (Kristall des Totalgeschehens) como um composto de pequenos eventos singulares (kleinen Einzelmoments). Para compreensão do todo é necessário analisar a minúcia; investigar o singular consiste na atividade imperativa no ensaio de compreensão do evento total.

Tanto o conhecimento por montagem como a imagem dialética podem ser problematizados dentro do escopo teórico benjaminiano através do conhecimento pelo caleidoscópio. O caleidoscópio de Benjamin foi pensado através do texto de Baudelaire Morale du joujou (1976) que abordou esse jogo ótico na cultura visual do século XIX. Este pequeno e simples dispositivo ótico fez furor em Paris, principalmente na transição da primeira para a segunda década do século XIX. Ele consistia em uma espécie de lanterna mágica inserida num mundo que experimentava as artes de luz e sombras - a fotografia e o cinema. Benjamin abordou a magia do caleidoscópio na "[...] perfeição fechada e simétrica das formas visuais que devem a sua riqueza inesgotável à imperfeição aberta e errática de uma pluralidade de fragmentos" (DidiHuberman 2005, 4).

Através do caleidoscópio, Benjamin expôs o duplo regime temporal da imagem. A chamada dialectique à l'arrêt do mecanismo produz a cada vez, a cada tentativa, uma diferente imagem originária através da combinação das mesmas peças. Tal jogo ótico exprime a imagem dialética, já que esta aborda um passado visto pelo presente através de um telescópio. O caleidoscópio é então um modelo teórico e um paradigma benjaminiano (Didi-Huberman 2005, 8). Cada ângulo e cada combinação daquele jogo caracterizaria a modernidade, pois o moderno é tão variável quanto os diferentes prismas do caleidoscópio (Benjamin, 2008). Além do mais, essa espécie de lanterna mágica funciona como um jogo, em que "se joga também entre um tempo da coisa desmontada e um tempo do conhecimento por montagem" (Didi-Huberman 2008, 183).

\section{O Atlas Mnemosyne e o (des)encaixar imagético de Aby Warburg}

Entre a imagem e o conhecimento por montagem, o nome de um historiador da arte alemão - que produziu sua obra no final do século XIX e início do século XX - destaca-se, consideravelmente. Aby 
Warburg, tal como Walter Benjamin, produziu uma maestra obra pautada na montagem. Como já foi expresso, o Atlas Mnemosyne (Warburg 2012) com suas 79 pranchas "finais" transborda de aleatoriedade, vitalidade e ritmo - os três elementos cernes do conhecimento por montagem para Didi-Huberman (2011, 92). O historiador da arte e filósofo francês repetidamente insiste nas distâncias sociais que separaram Walter Benjamin e Aby Warburg. Arriscadamente, podemos cogitar que este também seja um repetido exercício de questionamento de sua própria obra e de sua própria base teórica, já que ambos constituem os mais destacados teóricos de seus trabalhos.

Walter Benjamin e Aby Warburg foram dois judeus alemães que fizeram a "travessia" entre o século XIX e o XX. Benjamin encaixotou e desencaixotou sua biblioteca um sem-número de vezes em decorrência do regime nazista. A Biblioteca Warburg - aquela que deu vida a todas as ideias do grande erudito - também foi encaixotada e transladada em decorrência do mesmo regime. Todavia, Benjamin era um pobre errante e Warburg um erudito riquíssimo (Didi-Huberman 2008, 142). Contudo, ambos praticaram seu saber histórico colocando em prática montagens. Por sua vez, nosso teórico em questão - Georges Didi-Huberman - fez outra "travessia" de séculos: entre o XX e o XXI. Como Benjamin e Warburg, também é judeu, contudo não é nem alemão, nem pobre ou riquíssimo. Diferentemente de seus dois grandes teóricos, é um professor universitário de carreira muitíssimo bem consolidada. Através de seus seminários, livros e exposições, Didi-Huberman encontra, ainda em vida, grande reconhecimento de sua vastíssima obra.

Ao longo do século XX, o nome de Aby Warburg foi muito menos conhecido do que o de Walter Benjamin: sua obra não é de tamanha difusão, nem aceitabilidade. Entretanto, nas duas primeiras décadas deste século XXI verifica-se uma considerável ampliação nas edições de seus trabalhos. Fernando Checa $(2010,10)$ aponta que na segunda década do século XXI Aby Warburg destaca-se e afama-se na história da arte e da imagem. Resumidamente, seus textos recomeçariam a serem editado e lidos na Itália da década de 1960 (Careri 2003, 4). A partir da segunda metade do século XX, o afamado Instituto Warburg parece cessar, mesmo que timidamente, de renegar o nome de seu fundador com o lançamento de sua primeira biografia intelectual: redigida por Ernst Gombrich na década de 1970 (Gombrich 2015). Na contemporaneidade são muitos os exegetas warburguianos (Burucúa 2003), segundo sua última biografa - Marie Anne Lescourrent - e atualmente somam-se mais de três mil e cinquenta títulos de obras que fazem comentários warburguianos (Lescourrent 2014, 9).

A imagem merece especial destaque nos escritos de Aby Warburg, uma vez que este historiador da cultura a abordara de forma 
marcadamente nova já a partir de sua tese doutoral, sobre Sandro Botticelli, ainda no final do século XIX. Sua produção intelectual é perturbadoramente fragmentada e descontínua, não caracterizada por grandes volumes, mas por breves textos, geralmente direcionados a conferências (Recht 2012, 10). Como trabalho escrito que tinha por objetivo as cátedras universitárias, produziu apenas sua tese (Didi-Huberman 2015e, 7). Mas ao longo de seus muitos fracionados e interessantes escritos destacam-se três principais conceitos: Nachleben, Pathosformel, Mnemosyne (Didi-Huberman 2013, 41). Estas três formas de perceção e de análise imagética modificam sobremaneira o abordar da imagem na Modernidade, bem como se constituem imprescindíveis para pensar o conhecimento montagem elaborado por Warburg.

Esses três conceitos warburguianos nunca foram definidos pelo intelectual; contudo, constituem a base de entendimento de toda sua obra. O Nachleben seria a pós vida da imagem. Por exemplo, o movimento das drapearias das têmperas de Botticelli foi analisado por Warburg como a pós vida da imagem em movimento muito evocada pelos mármores da Antiguidade Greco-Romana. O Pathosformel foi cunhado com o intento de abordar a fórmula pathos. Ele estaria atrelado à pós vida das formas, em especial à repetição na gestualidade humana. Contudo, ao analisar tal repetição gestual, Warburg abordava a quase constante inversão de significado do mesmo gesto. Como um braço erguido pode, numa dada imagem, expressar protesto e, em outra, celebração. O nome da deusa grega Mnemosyne expressava a forma de ver warburguiana. Aby Warburg viu imagens como quem assistia a um grande teatro da memória. Ele acreditou numa espécie de fio que ligasse imagens, de diferentes tempos e lugares, pela memória humana.

Todas estas abordagens warburguianas da imagem foram ensaiadas no montar de seu Atlas Mnemosyne. O chamado Bilderatlas ganhou forma na sala oval de sua Kulturwissenschaftliche Bibliothek Warburg e constitui o último e inacabado trabalho de Aby Warburg, que grosso modo consistia na organização visual de seu pensamento. O projeto foi empreendido entre os anos de 1924 e 1929, mas é resultante de atividade que o erudito desenvolveu durante boa parte de sua vida. Warburg costumeiramente falava que aquele era o intento de contar uma história da arte sem palavras, que seu Atlas era "uma história de fantasmas para adultos." Até o momento de sua morte, em 1929, o Atlas compunha-se de 79 painéis: eram telas de madeira, de 1,5 por 2 metros, cobertas por tecido preto. Sob tais tecidos foram fixadas cópias de quadros, reproduções fotográficas, pedaços de periódicos, imagens e textos retirados de material gráfico - organizados, assim, a partir de eixos temáticos. A montagem dos painéis que compunham o Atlas não era necessariamente organizada de forma linear ou cronológica. 
O Atlas Mnemosyne aborda o campo das imagens, rompendo suas ordens cronológicas e logocêntricas. Aby Warburg é um intelectual que incorpora questões absolutamente novas no pensar e no trabalhar com imagens - ainda hoje no século XXI. "Estudar a obra de Warburg e seu esforço para ampliar a história da arte as dimensões de uma ciência cultural da imagem em movimento" (Sierek 2009, 22).

Os painéis de Aby Warburg propunham uma constelação de imagens e uma constelação de tempos. Os painéis eram compostos de uma infinidade de fotografias de imagens. Eram "imagens de imagens" dos mais diferentes modos de produção de diversos locais e tempos históricos. "Os grandes painéis de tecido preto em que se encontram justapostas reproduções de obras, bem como recorte de jornais, selos, páginas de livros, cartões-postais ou fotografias de diversas origens, compõem uma estranha paisagem" (Michaud 2013, 293). Para Philippe-Alain Michaud, esta nova organização imagética elaborou um novo estilo de apresentação dos fenómenos estéticos, onde o saber se transmuda em ritmo de orientação.

Melendi $(2010,19)$ escreve que o Atlas pretendia trazer o modelo, segundo o qual o humanismo europeu projetasse suas continuidades e apontasse suas origens. Projeto, painéis, o Atlas é a obra de um interessante nome que modifica o fazer pesquisa em arte e imagem já no início do século XX. Aby Warburg empreende o projeto de um Atlas Mnemosyne que propunha, segundo os próprios escritos do historiador, a construção de um modelo mnemónico, no qual o pensamento humanista europeu fosse capaz de apontar suas origens e rastrear suas permanências no século $\mathrm{XX}$, como continuidades latentes. Benjamin Buchloh assinala que, para Warburg, o rastreamento de inúmeras camadas de transmissão cultural poderia, de certa forma, apontar uma memória social coletiva (Buchloh 1999, 14).

Georges Didi-Huberman faz uma interessante comparação entre dois dispositivos comparativos de imagens utilizados por dois historiadores da arte num mesmo momento histórico. Se Aby Warburg montava suas imagens nas pranchas de seu Atlas Mnemosyne, para assim compará-las e pensá-las, Heinrich Wölfflin utilizava-se de dispositivos projetores na sala de aula para ministrar seus seminários. Wölfflin empregava dois dispositivos para projetar cada qual uma imagem: o seu intento também era comparativo. É de considerável importância ponderar que os dois grandes fundadores da moderna História da Arte inventaram, cada qual à sua maneira, formas de montagens produtoras de um novo saber sobre as imagens (Didi-Huberman 2010a, 156). Contudo, vale apontar que as montagens de Heinrich Wölfflin propunham comparações baseadas na bipolaridade, e as de Aby Warburg - em seu Atlas Mnemosyne baseavam-se na proliferação de polaridades. Ambos os intentos são contemporâneos não só às Passagens benjaminianas, cuja conceção 
inicial data de 1927-1929, como também às montagens cinematográficas de Sergueï Eisenstein.

\section{A (des)montagem de letras, palavras e frases em Eisenstein}

O cinema constitui saber montado. Dentro do escopo cinematográfico o nome de Sergueï Eisenstein destaca-se não apenas por seu fazer cinema, mas também por seu teorizar e escrever. Sergueï Eisenstein constitui questão central do penúltimo seminário realizado por Georges Didi-Huberman. Peuples en larmes, peuples en armes (Didi-Huberman, 2016) ganhou também edição pela Editora Minuit, fechando os seis tomos de L'œil de l'histoire ${ }^{4}$ - série cujo primeiro livro foi lançado no ano de 2009 - Quand les images prennent position (Didi-Huberman 2009). Tanto o seminário como o livro trataram da exímia e complexa obra do cineasta e teórico soviético. A partir dos escritos e das imagens de Eisenstein problematizou-se questões primordiais para um pensar imagem - como montagem, emoção, Pathosformel, sobrevivência, entre outras.

Montagem foi palavra maestra para Eisenstein, que tão bem a problematizou e a teorizou. Contudo, Didi-Huberman partiu de outro problema, também muito caro à imagem e às questões levantadas pelo cineasta: a emoção. A discussão iniciou-se com a abordagem da série fotográfica do livro A expressão das emoções nos homens $e$ nos animais, de Chales Darwin, que, de certa feita, já havia sido analisada por Didi-Huberman no pequeno livro ensaístico Que emoção! Que emoção? ${ }^{5}$ (Didi-Huberman 2015b). Em tal série fotográfica, as lágrimas foram analisadas por Chales Darwin como um gesto humano primitivo ainda muito visível nos modos expressivos de mulheres e crianças. Didi-Huberman assinala que, filosoficamente, a desvalorização das experiências emocionais data dos antigos gregos (Didi-Huberman 2016, 22).

A primazia da razão sobre o sensível é filosoficamente questionada há séculos. "A emoção opõe-se, por um lado, à razão" de Platão a Kant (Didi-Huberman 2015b, 22). Uma tradição filosófica desde Platão e Aristóteles e seguida por Descartes, Kant, Hegel defendeu uma universalidade dos juízos. Kant escreveu sobre a "universalidade" do conhecimento humano e a necessidade dos "princípios da razão" na Estética em sua Crítica da Razão Pura.

\footnotetext{
${ }^{4} L$ 'œeil de l'histoire foi uma série de livros de Georges Didi-Huberman editados pela Editora Minuit de 2009 a 2016. A série é composta por: Quand les images prennent position (2009); Remontage du temps subi (2010); Atlas, ou Le gai savoir inquiet (2011); Peuples exposés, peuples figurants (2012); Passés cités par JLG (2015); Peuples en Larmes, peuples en armes (2016).

${ }^{5}$ O livro Que emoção! Que emoção? é a transcrição de uma conferência, e de sua discussão, realizada para/e com crianças na cidade de Montreuil - cidade dos arredores parisienses. Atualmente, o livro também se apresenta disponível em edição brasileira (Didi-Huberman, 2015b) - nas referências deste artigo consta a edição portuguesa.
} 
Georges Didi-Huberman sublinha que na filosofia a emoção foi mal vista e que em Kant ela consiste na falha da razão (Didi-Huberman 2015b). Contudo, a partir de Friedrich Nietzsche (2013) a primazia da razão passou a ser questionada.

A emoção, expressa na gestualidade humana, pode ser visualizada em um sem-número de imagens em nossa ocidentalidade. A escultura helenística do Laoconte (50 d.C.) é um ótimo exemplo, analisado tanto por Aby Warburg, como por Didi-Huberman. Esse pathos da paixão, ou da emoção, também pode ser visualizado nas montagens cinematográficas d'O Encouraçado Potemkine (1925). Como primeira cena: o homem que morre - Vakoulintchouk, um proletário que contesta sua condição de vida miserável - e as mulheres que choram. Cena aludida repetidamente por todas as tragédias (Didi-Huberman 2016, 79), foi utilizada por Georges DidiHuberman para iniciar suas análises acerca da montagem cinematográfica de Eisenstein. A morte do homem transforma-se no protesto de seus camaradas. O povo que pede por justiça - um povo em lágrimas que se transforma num povo em armas. Nesta análise didi-hubermaniana, a figura de Odessa recebe grande destaque, a mulher que lamenta e cuja gestualidade de prantos e luto transforma-se em gestualidade de luta e protesto.

Para nosso historiador de um mais que passado pode-se ponderar que $O$ Encouraçado Potemkine está para o cinema assim como O nascimento da tragédia (Nietzsche, 1872) está para filosofia. A película de Eisenstein conta-nos sobre o nascimento de um povo revolucionário. $\mathrm{O}$ nascimento dessa potência que emerge de extrema dor, como as análises de Nietzsche acerca da arte grega entre o pathos dionisíaco e o ethos apolíneo. A partir de tal perspetiva, não existe nem beleza nem nascimento que não estejam trasbordados de dor: o apolíneo não pode ser compreendido sem o dionisíaco. O filme não narra a chegada ao poder, mas apresenta os gestos da potência que nasce a partir do sofrimento, do despoder e da emoção de um povo humilhado e explorado.

A cena da lamentação em O Encouraçado Potemkine foi analisada a partir de escolhas formais de uma montagem cinematográfica - como figurinos, luminosidade, ângulos, direção de atores. A emoção é apresentada dialeticamente nas suas dimensões singulares e coletivas (Didi-Huberman 2016, 236). A perspetiva fragmentada, repetitiva e polarizada dessa cena de lamentação foi denominada por Eisenstein de montagem rítmica. Nela, os gestos de cada um correspondem ao gesto de todos (Didi-Huberman 2016, 264). Tal observação foi remetida às telas Leonardo da Vinci, que exprimem magistralmente tanto o elemento de um próximo, como o de um longe: detalhe e atmosfera. A lamentação na película é apresentada tanto na gota de lágrima de cada mulher, como na própria bruma da cena; seria um lamento de brumas colorido, por Eisenstein, com uma infinita possibilidade de cinzas. 
$\mathrm{Na}$ face de cada uma daquelas mulheres em pranto podemos ver as marcas, não só de tristeza, mas também de resignação religiosa e mesmo de raiva: para Didi-Huberman, elas choram dialeticamente (Didi-Huberman 2016, 279). A gestualidade dessas mulheres aponta também contrariedades, o que foi analisado a partir da fórmula patética (Pathosformel) de Aby Warburg, na qual o mesmo motivo repete-se e muitas vezes se contradiz.

Algumas viagens realizadas por Sergueï Eisenstein podem auxiliar a compreensão de sua problematização acerca da montagem. Entre 1929 e 1930 esteve na Alemanha, Suíça, Holanda, Bélgica, Inglaterra e na França. Em Paris, estabeleceu contato com Surrealismo - e os surrealistas -, movimento artístico marcado tanto pela antropologia quanto pela operação de montagens (Somaini 2013, 252). Entre 1930 e 1932, Eisenstein viajou ao México e deparou-se com a configuração de um país entre uma montagem de culturas pré-colombianas e europeias. No inacabado filme Que Viva México (1931) foi desenvolvida montagem tanto cinematográfica, quanto gráfica que apresentou uma cultura montada - de mistura de crenças, religiões com uma superposição de tradições iconográficas e religiosas. "Eisenstein percebeu o México não como um território unilateral dotado de uma cultura própria, mas como uma vertiginosa montagem temporal de heterogeneidades - históricas, sociais, religiosa, artísticas, políticas [...]” (Didi-Huberman 2016, 349).

O pensamento de Eisenstein e o do historiador da arte e da cultura Aby Warburg têm singular coincidência; contudo, nenhum indício leva a crer que um tenha contatado com o trabalho do outro. Pode-se sublinhar no trabalho de ambos a importância das religiões e rituais, a viagem a América, a montagem, a fórmula do pathos. As experiências de Eisenstein no México e de Warburg no Novo México acabam por problematizar a convicção da natureza da imagem pela perspetiva antropológica, e a transmissão de tais imagens pelo tempo - para Warburg pelo Nachleben; para Eisenstein pela "recorrência." Grosso modo, os dois estudiosos deparam-se com um problema singular: a sobrevida e as variações nas reaparições imagéticas, o que para Warburg seria o Pathosformel e para Eisenstein pafossa (Somaini 2013, 278). Eisenstein teoriza acerca da formula pafossa "projetada como fórmula energética e transhistórica onde ele pesquisa as manifestações e as variações dentre toda uma série de obras onde podemos encontrar algumas no Atlas Mnemosyne, como o Laocoon do Grego" (Somaini 2013, 264).

Sergueï Eisenstein destacou-se não só por seu exímio fazer cinematográfico, como também por seus escritos sobre o cinema. Dentre contribuição inquestionável, a teorização da montagem obtém especial visibilidade. Tal conceito foi elaborado por Eisenstein entre os anos de 1923 e 1948. Desta maneira, não se pode afirmar a

\footnotetext{
${ }^{6}$ Tradução livre da autora com base no texto original em francês.
} 
existência de uma única teoria da montagem eisensteniana, mas de várias elaboradas ao longo de 25 anos de imensa dedicação teórica. $\mathrm{O}$ cineasta escreveu milhares de páginas acerca da imagem, as quais atualmente podem ser encontradas desde em $A$ não-indiferente natureza do cinema até às Notas para uma História Geral do cinema e a Método (Didi-Huberman 2015c, 38).

Antonio Somaini (2013) sublinha que a montagem não se reduz ao cinema, que constitui uma maneira de operar. A própria forma de escrita de Eisenstein operou nessa montagem. Montagem, grosso modo, constitui um processo artístico, transmidiático e transhistórico. Na elaboração conceitual do termo, o cineasta perpassa não apenas o cinema, mas também desenho, pintura, escultura, arquitetura, teatro, literatura, música. Em suas Notas para uma História Geral do Cinema, Sergueï Eisenstein exemplifica montagens que antecedem as cinematográficas. Na passagem "Herança," o cinema é apresentado como capaz de produzir uma síntese que se insere em linha genealógica que perpassa desde os gregos. "O cinema é o herdeiro de todas as culturas artísticas, é o herdeiro de todas as culturas de séculos precedentes" (Eisenstein 2013, 23).

Para o cineasta soviético, a junção de dois fragmentos, quando justapostos - não importando se são relacionados entre si - concebe uma terceira coisa. "Esta propriedade consiste no fato de que dois pedaços de filme de qualquer tipo, colocados juntos inevitavelmente criam um novo conceito, uma nova qualidade, que surge da justaposição" (Eisenstein 2002, 14). Sergueï Eisenstein elabora tal montagem em detrimento da montagem da cena de um filme - uma montagem cinematográfica; contudo, sublinha que a montagem pode ser visualizada não apenas no cinema: ele a compreende como "um fenômeno encontrado sempre que lidamos com a justaposição de dois fatos, dois fenômenos, dois objetos (Eisenstein 2002, 14).

Torna-se também interessante destacar a montagem como atividade mútua, também composta por seu espetador, como tão bem destacou Eisenstein. O sentimento do espetador é incluído ao processo criativo, a ele também cabe criar. "O espetador não apenas vê os elementos representados na obra terminada, mas também experimenta o processo dinâmico de surgimento e reunião da imagem, exatamente como foi experimentado pelo autor" (Eisenstein 2002, 29). A montagem é fórmula de conceção eficaz capaz de agir no espetador, que inicia um processo intelectual a partir dessas montagens. Seu papel é ativado ao ligar elementos heterogéneos, o que não se dá apenas no nível das operações conscientes.

Em boa parte de seus textos, o teórico do cinema refletiu acerca das relações entre cinema e história da arte (Somaini 2013, 237). Todavia, entre eles destacam-se as suas Notas para uma História Geral do Cinema, que constituem o intento de explicar o cinema através da reconstrução respetiva de toda sua história e 
compreendem seus desenvolvimentos futuros através de uma genealogia - que é também uma morfologia, uma arqueologia das imagens e uma arqueologia das Mídias (Somaini 2013, 238). Todas as Mídias, técnicas e formas experimentam todas as configurações de montagens antes do cinema.

Uma genealogia da montagem cinematográfica é pensada através de uma sequência de obras, espetáculos populares, movimentos artísticos, técnicas. A genealogia perpassa a representação do corpo humano do Antigo Egito, o pontilhismo, vitrais góticos, telas renascentistas, máscaras funerárias - o intuito é apresentar os fenómenos originais, ou fundamentais da montagem, na história da arte. Sergueï Eisenstein constrói um grande museu imaginário de imagens, compondo um verdadeiro pensar montagem. Pelas Notas para uma História Geral do Cinema perpassam três questões centrais: 1) o lugar do cinema na história da arte, 2) os precursores do cinema nessa mesma história, 3) os fundamentos psicológicos e culturais do cinema, pensado como parte de uma vasta antropologia das imagens e arqueologia das Mídias (Somaini 2013, 250).

O pensamento de Sergueï Eisenstein é anacrônico - ele não se dá através do tempo organizado e linear. As imagens apresentam uma história descontínua e não linear, anacrônica, na qual as sobrevivências são sempre colocadas. A montagem constitui sua própria maneira de operar "o uso da montagem como estilo de escrita, como forma de pensar e como princípio heurístico e hermenêutico para a análise e comparação morfológica entre formas artísticas, expressões e rituais provenientes de tradições e de culturas diferentes" (Somaini 2013, 238).

Eisenstein escolheu um deus para figurar como personagem de sua conceção de montagem. Como leitor de Nietzsche, recorreu à cultura clássica, ao deus da dança grego: Dionísio. Nietzsche em seu Nascimento da tragédia é colocado, indiretamente, em referência a esse deus que se destrói de sua unicidade. Dionísio é filho de Zeus com uma humana. Conhecido como o deus grego do vinho e da dança, tem como referência romana Baco. Os cultos dionisíacos marcaram-se pelo consumo de álcool, orgias, danças e sacrifícios. Operando sua dança, Dionísio cortava-se em pedaços e reconstituía seu corpo. De tal feita, os ritos dionisíacos são cerimoniais mitológicos da montagem, de desunificação e reunificação em um rito sacrificial de um deus. Para Georges Didi-Huberman, a montagem é uma operação dionisíaca (Didi-Huberman 2016, 176), a reunificação corpórea de Dionísio constrói um corpo transfigurado.

O deus grego Dionísio é o deus do ritmo, da dança e da montagem. O deus que se transforma em pedaços, dilacera-se, fragmentase, para então montar-se, remontar-se, colocar-se em forma novamente (Didi-Huberman 2016, 175). Nas Notas para uma História do Cinema, Eisenstein coloca a figura de Dionísio, do deus que morre e 
renasce repetidamente, como crucial para pensar o saber montagem. "A montagem é uma operação dionisíaca: coloca-se em pedaço, corta-se de sua continuidade, assassina-se num senso e, portanto, é lá que se faz justamente mudar, dançar, viver. É um nascimento cruel, um nascimento por desmembramento obrigatório" (Didi-Huberman 2016, 176).

Georges Didi-Huberman sublinha Eisenstein como um cineasta em pedaços, seus filmes foram montados e remontados não apenas pelo seu próprio fazer cinema, mas também pela censura: tanto soviética, como ocidental. Seu fazer cinematográfico é ressaltado pelos fragmentos e planos curtos - ritmicidade, gestualidade e explosão do pathos. Para além de um cineasta em pedaços, Eisenstein foi um escritor em pedaços (Didi-Huberman 2016, 178) produziu vasto material - visual e textual - no decorrer de anos de escrita. Seus manuscritos são repletos de traços que montam e desmontam palavras e desenhos: ao lê-los temos a sensação de também estarmos fazendo parte desta operação de montagem. Conhecendo suficientemente a obra de Eisenstein, sabemos que foi exatamente esta a sua intenção. Nos colocamos no lugar de um espetador/leitor que também faz parte dessa operação inacabada de montagens.

\section{A (des)montagem como maneira de operar}

O presente texto abordou a montagem na obra de Georges DidiHuberman. Para tal, foram principalmente problematizadas e analisadas duas questões: imagem e tempo. Montagem, imagem e tempo atravessam boa parte da obra do filósofo e historiador da arte em questão. Contudo, este texto discutiu tais quesitos a partir de três autores essenciais: Walter Benjamin, Aby Warburg e Sergueï Eisenstein. Com o suporte das premissas de cada um deles, buscouse examinar o papel e a contribuição de suas pesquisas na compreensão e na formação das montagens imagéticas tão defendida por DidiHuberman.

As obras de Walter Benjamin, Aby Warburg e Sergueï Eisenstein caracterizam-se, de certo modo, por terem sido feitas em pedaços. Eles passam, em alguma etapa de seus processos intelectuais, por essa espécie de escrita em migalhas, o que proporciona aos leitores fazerem também parte dessa incrível montagem teórica. Fernando Checa escreve que Warburg teria mais intérpretes do que leitores, o que também se aplica a Benjamin e a Eisenstein. Suas escritas fracionadas proporcionaram a fissura essencial para que o leitor fizesse seus próprios encaixes ao ler os textos, constituindo-se assim também como autor nessa operação de montagens.

Os três teóricos formam alicerce base para perpassar a compreensão da montagem como defendida por Georges DidiHuberman. Contudo, a montagem didi-hubermaniana não se limita a 
estes três eruditos. Este breve ensaio abordou estes três intelectuais em virtude do destaque que eles recebem na obra do filósofo e historiador da arte.

O teórico em questão apresenta considerável e densa obra. Não podemos afirmar que seu processo de escrita se caracterize nem por migalhas, nem por fragmentações. Ao contrário, o historiador da arte apresenta um constante e contínuo processo de escrita. Também, ao contrário de Benjamin e Warburg, Didi-Huberman encontra em vida repercussão e reconhecimento tanto académico, como intelectual - reconhecimento este desconhecido por seus dois principais teóricos. Para além de diretor de pesquisa de uma das mais renomadas instituições francesas em ciências sociais (EHESS de Paris), Didi-Huberman possui contrato com a afamada casa de edição parisiense Les Éditions de Minuit. Além do mais, atua como curador de exposições, e universidades e museus de todo o mundo disputam suas falas e conferências.

Escrita, pesquisa e trabalho constantes jamais poderiam desqualificar a obra de um grande intelectual. Georges DidiHuberman- diferentemente de seus mestres - soube organizar e sistematizar suas pesquisas e seu processo de escrita, bem como cativar um público que lhe segue. Provavelmente este será o aspeto que o diferencia tanto dos demais intelectuais aqui citados. Talvez ele defenda tanto a montagem pois é - como de certa feita todos nós somos - feito a partir dela. Todos somos montagens de imagens, textos, experiências. Georges Didi-Huberman opera neste saber montagem, pois é a montagem de uma imensa base teórica e filosófica. Ele colocou Benjamin, Warburg e Eisenstein lado a lado e encontrou uma outra coisa, que não pode ser vista em nenhum deles separadamente. Nessas páginas busquei desmontar um mestre, deixá-lo em pedaços. Aqui o intento foi desmontar para entender seu funcionamento.

\section{BIBLIOGRAFIA}

Alberti, Leon Batista. 2015 (1452). Da Pintura. Campinas: Editora Unicamp.

Benjamin, Walter. 2010 (1940). Passagens. Belo Horizonte/São Paulo: Editora UFMG/Editora Imprensa Oficial do Estado de São Paulo.

-—-. 2002 (1985). Obras Escolhidas I. Magia e técnica, arte e política. São Paulo: Editora Brasiliense.

Bloch, Marc. 2002 (1964). Apologia da história ou o ofício do historiador. Rio de Janeiro: Editora Zahar. 
Buchloh, Benjamin. 1990. "Gerhard Richter's Atlas: the anomic archive." In Photography and Painting in the Work of Gerhard Richter, 11-30. Barcelona: Libres Recerca Arte 6.

Burucúa, José Emilio. 2003. Historia, arte, cultura: De Aby Warburg a Carlo Ginzburg. Madrid: Fondo de cultura económica.

Careri, Giovanni. 2003. "Aby Warburg. Rituel, Pathosformel et forme intermédiaire”. L'Homme v. 1, n. ${ }^{\circ}$ 165: 41-76.

Checa, Fernando. Prefacio. 2010. In: F. Checa e S. Settis. Warburg continuatus: descripción de una biblioteca. Barcelona/Madrid: Ediciones la Central.

Didi-Huberman, Georges. 1999. Ouvrir Vénus. Nudité, rêve, cruauté. Paris: Gallimard.

-—-. 2002. L'image survivante. Histoire de l'art et temps des fantômes selon Aby Warburg. Paris: Les éditions de Minuit.

-_- 2004 (2003). Imágenes pese a todo: memoria visual del Holocausto. Barcelona: Ediciones Paidós.

- - . 2005. "Connaissance par kaleidoscope. Morale du joujou et dialectique de l'image selon Walter Benjamin" Revue Études photographiques, n.7 (7 mai).

- - . 2008 (2000). Ante el tiempo. Historia del arte y anacronismo de las imágenes. Buenos Aires: Adriana Hidalgo editora.

-_- 2009. Quand les images prennent position. L'œil de l'histoire, 6. Paris: Les éditions de Minuit.

-_-. 2010a. Remontage du temps subi. L'œil de l'histoire, 2. Paris: Minuit.

-_-. 2010b (1992). O que vemos, o que nos olha. São Paulo: Editora 34.

-_-. 2011. "La condition des images". In M. Augé, G. Didi-Huberman e U. Eco, L'expérience des images. Paris: INA Éditions.

-—-. 2015a (1984). Invenção da histeria. Charcot e a iconografia fotográfica da Salpêtrière. Rio de Janeiro: Editora Contraponto.

- - 2015b (2013). Que emoção! Que emoção? Lisboa: KKYM.

-—-. 2015c. Passés cités par JLG. L'œil de l'histoire, 6. Paris: Les éditions de Minuit.

- - . 2015d. "L'ivresse des formes et l'illumination profane". In G. Careri e G. Didi-Huberman, L'histoire de l'art depuis Walter Benjamin. Paris: Éditions Mimésis.

-—-. 2015e. Ninfa fluida. Paris: Gallimard.

-—- 2016. Peuples en larmes, peuples en armes. L'œil de l'histoire, 6. Paris: Les éditions de Minuit.

Eisenstein, Sergueï. 2013 (1948). Notes pour une histoire générale du cinéma. Paris: AFRHC.

-——. 2002 (1942). O sentido do filme. Rio de Janeiro: Zahar. 
Gombrich, Ernst Hans e Fritz Saxl. 2015 (1977). Aby Warburg: une biographie intellectuelle. Suivie d'une étude sur l'histoire de la bibliothèque de Warburg. Paris: Klincksieck.

Kant, Emmanuel. 2006 (1972). Crítica da razão pura. São Paulo: Editora Zahar.

Lescourrel, Marie Anne. 2014. Aby Warburg et la tentation du regard. Paris: Hazan.

Melendi, Maria Angélica. 2010. "A solidez do arquivo: Entre pedras soterradas e fotografias esquecidas". In Encantos da Imagem: Estâncias para a prática historiográfica entre história e arte, ed. por Bernardete Ramos Flores e Ana Lúcia Vilela, 70-91. Blumenau: Letras Contemporâneas.

Michaud, Philippe-Alain. 2013 (2002). Aby Warburg e a imagem em movimento. Rio de Janeiro: Contraponto.

Nietzsche, Friedrich. 2011 (1928). A origem do drama trágico alemão. Belo Horizonte: Editora Autêntica.

Recht, Roland. 2012. "L'Atlas Mnémosyne d'Aby Warburg” In L'Atlas Mnémosyne. Paris: l’Écarquillé.

Seligmann-Silva, Márcio. 2016. "Walter Benjamin: a fotografia como segunda técnica". Revista Maracanan n. ${ }^{\circ} 14$ (jan/jun): 58-74.

-_- 1993. "Prefácio: A Redescoberta do Idealismo Mágico". In O conceito de crítica de arte no romantismo alemão, de Walter Benjamin, tradução, introdução e notas de Márcio Seligmann-Silva, 9-14. São Paulo: Iluminuras.

Settis, Salvadore. 2010 Warburg Continuatus. Descripción de una biblioteca. Barcelona: Ediciones de La Central, Museu Nacional de Arte Reina Sofia.

Sierek, Karl. 2009. Images oiseaux: Aby Warburg et la théorie des médias. Paris: Klincksieck.

Somaini, Antonio. 2013. "Généalogie, morphologie, anthropologie des images, archéologie des médias". In Sergueï M. Eisenstein, Notes pour une histoire générale du cinéma, 237-284. Paris: AFRHC.

Warburg, Aby. 2012 (1939). L'Atlas Mnémosyne. Paris: l'Écarquillé.

- - 2015 (1893). "O nascimento de Vênus e A primavera de Sandro Botticelli”. História de fantasmas para gente grande. Escritos, esboços e conferências, org. Leopoldo Waizbort, trad. Lenin Bicudo Bárbara, 27-85. Rio de Janeiro: Companhia das Letras.

Recebido em 20-12-2016. Aceite para publicação em 08-05-2017. 